\title{
Pengembangan Media Mobile Learning dengan Pendekatan Saintifik Berbasis Keterampilan Berpikir Kritis Matematis Siswa Kelas XI Madrasah Aliyah
}

\author{
Rini Mariani ${ }^{1}$, Jefri Marzal ${ }^{2}$, Zurweni ${ }^{3}$ \\ ${ }^{1,2}$ Program Studi Magister Pendidikan Matematika, Fakultas Keguruan dan Ilmu Pendidikan, Universitas Jambi, \\ J1. Raden Mattaher No 16, Jambi, Indonesia \\ rinimariani110384@email.com
}

\begin{abstract}
This research is a type of development research. This study aims to (1) describe how the process of critical thinking skills resulting from the development of mobile learning media using the Smart Apps Creator (SAC) 3 application on derived material in class XI MIA; (2) describe the feasibility of mobile learning media in theory and practice; (3) describe the effectiveness of mobile learning media. To achieve this goal, a mobile learning media based on mathematical critical thinking skills was developed using the Lee and Owens development model. This media was validated by experts and assessed by the teacher and then tested on small group and large group students. The feasibility of learning media refers to three aspects, namely validity, practicality, and effectiveness. The theoretical feasibility was obtained from expert validation, while the practical feasibility was obtained from small group trials and large group trials with very practical criteria. The results of the teacher assessment questionnaire obtained a percentage of $89 \%$, small group trials $86 \%$ and large group trials with a percentage of 87.5\%. To see the effectiveness of the media, pretest and posttest were conducted to see students' critical thinking skills before and after using the media. To measure students' critical thinking skills, the n-gain test is used. Based on the results of the N-Gain test, the results obtained in the high category. Based on these results, it can be concluded that mobile learning media is feasible to use to improve students' mathematical critical thinking.
\end{abstract}

Keywords: Media, mobile learning, scientific approach, critical thinking skills

\begin{abstract}
Abstrak
Penelitian ini merupakan jenis penelitian pengembangan. Penelitian ini bertujuan untuk (1) mendeskripsikan bagaimana proses keterampilan berpikir kritis yang dihasilkan dari pengembangan media mobile learning menggunakan aplikasi Smart Apps Creator (SAC) 3 pada materi turunan di kelas XI MIA; (2) mendeskripsikan kelayakan media mobile learning secara teori dan praktis; (3) mendeskripsikan efektivitas dari media mobile learning. Untuk mencapai tujuan tersebut, dikembangkan media mobile learning berbasis keterampilan berpikir kritis matematis dengan model pengembangan Lee dan Owens. Media ini divalidasi oleh ahli dan dinilai oleh guru kemudian diujicobakan pada siswa kelompok kecil dan kelompok besar. Kelayakan media pembelajaran mengacu kepada tiga aspek yaitu kevalidan, kepraktisan dan keefektifan. Kelayakan secara teori diperoleh dari validasi ahli, sedangkan kelayakan secara praktis diperoleh dari ujicoba kelompok kecil dan uji coba kelompok besar dengan kriteria sangat praktis. Hasil angket penilaian guru diperoleh persentase $89 \%$, ujicoba kelompok kecil $86 \%$ serta ujicoba kelompok besar dengan persentase $87,5 \%$. Untuk melihat efektifitas media dilakukan pretest dan post test untuk melihat keterampilan berpikir kritis siswa sebelum dan sesudah penggunaan media. Untuk mengukur keterampilan berpikir kritis siswa digunakan uji n-gain. Berdasarkan hasil uji N-Gain diperoleh hasil dengan kategori tinggi. Berdasarkan hasil tersebut, sehingga diperoleh kesimpulan bahwa media mobile learning layak digunakan untuk meningkatkan berpikir kritis matematis siswa.
\end{abstract}

Kata kunci: media, mobile learning, pendekatan saintifik, keterampilan berpikir kritis

Copyright (c) 2021 Rini Mariani, Jefri Marzal, Zurweni

$\triangle$ Corresponding author: Rini Mariani

Email Address: rinimariani110384@email.com (Jl. Raden Mattaher No 16, Jambi, Indonesia)

Received 03 July 2021, Accepted 21 November 2021, Published 30 November 2021

\section{PENDAHULUAN}

Pendidikan merupakan salah satu faktor yang sangat berpengaruh dalam kehidupan manusia. Sebagai ujung tombak pembangunan, pendidikan memegang peranan yang sangat penting. Karena begitu pentingnya pendidikan, dibutuhkan kerjasama semua pihak untuk meningkatkan kualitas pendidikan. Untuk menghasilkan pendidikan yang berkualitas, dibutuhkan sumber daya manusia (SDM) 
yang handal, terampil, dan memiliki daya cipta yang tinggi (Salahuddin et al., 2018; Wijaya et al., 2016). Dalam rangka mempersiapkan generasi yang siap menghadapi dunia kerja pada abad 21, salah satu pihak yang berperan penting adalah dunia pendidikan, terutama sekolah dan guru. Sekolah sebagai output dari peserta didik yang akan mencetak generasi penerus yang siap bersaing di dunia kerja (Huda et al.,2011). Oleh karena itu, peserta didik hendaknya dibekali dengan kecakapan/keahlian yang sesuai dengan abad 21.

Pembelajaran abad 21 adalah sebuah pembelajaran yang memberikan kecakapan abad 21 kepada peserta didik yang meliputi 4 C (Tang et al., 2020). Salah satu aspeknya adalah Critical Thinking (keterampilan berpikir kritis). Pembelajaran di abad 21 ini tidak hanya berpusat pada kemampuan kognitif saja, tetapi juga mencakup sejumlah keterampilan personal dan sosial. Hal ini sesuai dengan Zubaidah (2010) menyatakan bahwa keterampilan berpikir terutama dalam memecahkan masalahmasalah merupakan kemampuan yang harus dimiliki seseorang agar berhasil dalam kehidupannya. Keterampilan berpikir kritis sangat penting dikuasai oleh siswa agar siswa lebih terampil dalam menyusun sebuah argumen atau membuat keputusan (Sulistiani \& Masrukan, 2016). Keterampilan berpikir kritis seyogyanya diterapkan pada semua jenjang pendidikan dan semua mata pelajaran. Salah satu alat untuk mengembangkan kemampuan kritis siswa adalah matematika. Matematika dan keterampilan berpikir kritis adalah dua hal yang saling berkaitan dimana pada pembelajaran matematika, peserta didik dituntut untuk berpikir kritis. Dengan berpikir kritis sejak dini, siswa sudah terbiasa dengan tantangan tantangan dan dalam mengambil keputusan dengan pertimbangan yang matang.

Adapun ciri-ciri keterampilan berpikir kritis terdiri dari beberapa komponen, antara lain: mengenal masalah, menemukan cara dalam menangani masalah, mengumpulkan dan menyusun informasi, menganalisis data, menilai fakta dan mengevaluasi (Watson \& Glaser, 2010). Selanjutnya, menurut Ennis (2011) dari komponen komponen diatas, dikelompokkan dalam lima aktivitas besar, yaitu:

1. Memberikan penjelasan sederhana,

2. Membangun keterampilan dasar

3. Menyimpulkan

4. Memberikan penjelasan lanjut

5. Mengatur strategi dan taktik

Berdasarkan pengalaman dan observasi pada pembelajaran di kelas pada kurikulum 2013, guru dalam mengajar cenderung menggunakan model pembelajaran konvensional dimana pembelajaran masih berpusat pada guru. Dalam pembelajaran, guru menggunakan buku cetak atau LKS (Lembar Kerja Siswa) yang tersedia sehingga menyebabkan siswa kurang dilibatkan dalam pembelajaran. Pada pembelajaran yang biasa kita jumpai, guru yang aktif (teacher centered), siswa hanya sebagai penyimak, pendengar dan mencatat apa yang disampaikan guru dan mengerjakan soal yang diberikan yang sesuai dengan contoh. Soal-soal evaluasi yang diberikan belum berorientasi untuk mengembangkan 
keterampilan berpikir siswa, sehingga siswa kurang dilatih dalam mengerjakan soal soal tersebut. Siswa kesulitan menganalisis informasi yang ada, siswa cenderung menerima apa adanya informasi yang disampaikan maupun yang tertulis dalam buku, pasif dalam mengajukan pertanyaan dari permasalahan yang telah diberikan guru, kurang percaya diri dalam mengemukakan jawaban dari permasalahan yang dikemukakan oleh guru (Wijayanti et al., 2019).

Untuk meningkatkan keterampilan berpikir kritis siswa, dibutuhkan media dan pendekatan yang tepat. Melalui bermacam macam pendekatan dan media dapat meningkatkan prestasi belajar siswa serta dapat mengarahkan siswa dalam memecahkan masalah yang dihadapi (Kabunggul et al., 2020). Selain itu, perlu diciptakan suasana belajar yang dapat membuat siswa lebih aktif dan termotivasi dalam belajar (Kabunggul et al., 2020). Salah satu pendekatan yang dapat digunakan yaitu pendekatan saintifik. Urutan logis pada pendekatan saintifik meliputi 5 hal yaitu: (1) mengamati, (2) menanya, (3) mengumpulkan informasi/mencoba, (4) menalar/mengasosiasi, dan (5) mengomunikasikan, yang selanjutnya akan disingkat dengan $5 M$. Urutan logis sebagaimana dimaksud dapat dikembangkan dan digunakan dalam satu atau lebih pertemuan (Kemendikbud, 2014a). Pendekatan saintifik dirancang sedemikian rupa sehingga siswa ikut terlibat aktif dalam pembelajaran dalam mengkonstruksi pengetahuan, keterampilan dan lainnya yang meliputi lima hal, yaitu mengamati, menanya, mengumpulkan informasi, menalar dan mengkomunikasikan sehingga proses berpikir siswa semakin terasah (Hosnan, 2014).

Perkembangan teknologi yang semakin cepat, salah satunya adalah penggunaan internet (Said et al., 2018). Hampir semua lini masyarakat telah menggunakan handphone sebagai alat komunikasi, begitu pula dengan peserta didik dan guru. Untuk itu dikembangkan media mobile learning, dimana mobile learning ini juga sangat cocok saat pandemi covid 19 melanda semua penjuru dunia, dimana semua pembelajaran dialihkan dari rumah dan memanfaatkan teknologi dan elektronika dalam segala aspek kehidupan (Samsinar, 2020). Tak terkecuali di sekolah, semua kegiatan pembelajaran dialihkan dengan penggunaan gadget. Mobile learning merupakan salah satu media pembelajaran yang memanfaatkan teknologi dan informasi yang memudahkan dalam pembelajaran sehingga pembelajaran dapat dilakukan kapan saja dan dimana saja tanpa terkendala ruang dan waktu (Wulandari et al., 2019). Mobile learning mengacu kepada perangkat informasi dan teknologi genggam dan bergerak dapat berupa telepon seluler, laptop, tablet dan lain-lain (Suryani et al., 2017).

Selain pendekatan, media dalam pembelajaran juga memegang peranan yang penting yang tidak boleh kita abaikan. Pemilihan media yang tepat dapat menunjang keberhasilan proses pembelajaran (Suryani et al., 2017). Untuk itu, peneliti mencoba menggunakan media yang menggunakan smartphone karena smartphone bukan barang yang langka lagi saat ini. Hampir semua peserta didik mempunyai smart phone dengan operasi sistem (OS) android (Lestari et al., 2019). OS android selain dimanfaatkan untuk social media (facebook, twitter, whatsapp, line dan lain-lain) dan game, saat ini smartphone telah bergeser dan digunakan dalam pembelajaran (Lestari et al., 2019). Agar penggunaan 
smartphone berbasis android menjadi optimal dikalangan pelajar usia tingkat SD sampai tingkat SMA, smartphone bisa digunakan sebagai media dalam pembelajaran (A. A. Nugroho \& Purwati, 2015). Hal ini adalah suatu prospek pengembangan media pembelajaran yang sangat efektif di zaman sekarang. Penggunaan android dapat digunakan sebagai alternatif dalam penggunaan media pembelajaran di sekolah. engan adanya media membuat siswa lebih tertarik untuk mempelajari matematika sehingga hasil belajar yang diperoleh juga semakin baik (Junita, 2019)

Salah satu materi yang dipelajari ditingkat SMA/MA adalah materi turunan. Materi turunan merupakan materi wajib yang harus dipelajari oleh siswa kelas XI SMA/MA pada jurusan Matematika dan Ilmu Alam (MIA). Pada materi turunan, sebagian siswa kesulitan dalam mencari turunan fungsi, menentukan interval pertidaksamaan pada fungsi naik dan fungsi turun serta mengubah soal cerita menjadi model Matematika untuk mencari penyelesaian (Apriliyanto, 2019; Lestari et al., 2019). Oleh karena itu, diperlukan suatu media yang dapat membantu siswa dalam memahami materi turunan. Salah satu media yang dapat digunakan adalah Smart Apps Creator 3 (SAC 3) untuk membuat pembelajaran menjadi lebih menarik dan interaktif. SAC 3 adalah software yang digunakan untuk membuat multimedia interaktif berbasis android (Khaer, 2018). Keunggulan saat menggunakan SAC 3.0 yaitu dapat membuat media pembelajaran sesuai dengan kebutuhan, tidak diperlukan koding atau fungsi khusus untuk menjalankan perintah atau interaksi. Selain itu terdapat banyak objek dapat dikombinasikan dalam multimedia yang dibuat. Enam menu yang digunakan dalam pembuatan multimedia pembelajaran yakni edit, insert, template, animation, interaction dan page. Jadi SAC ini sangat cocok untuk tenaga pendidik yang ingin berinovasi membuat media pembelajaran android walaupun tidak memiliki skill pemrograman apapun (Khaer, 2018).

\section{METODE}

Penelitian ini menggunakan model pengembangan Lee dan Owens. Model ini dipilih karena model Lee dan Owens dikhususkan untuk mengembangkan mutimedia. Model pengembangan ini dikatakan sebagai model prosedural karena urutan langkah dalam prosesnya tersusun secara sistematis dan jelas. Model Pengembangan ini didesain dengan menggunakan lima tahap meliputi tahap analisa (analyze) yang meliputi analisis kebutuhan dan analisis awal akhir, desain (design), pengembangan (develop), implementasi (implementation), dan penilaian (evaluate). Tahapan dari model Lee, W.W and Owens, D.L dapat dilihat pada gambar 1. 


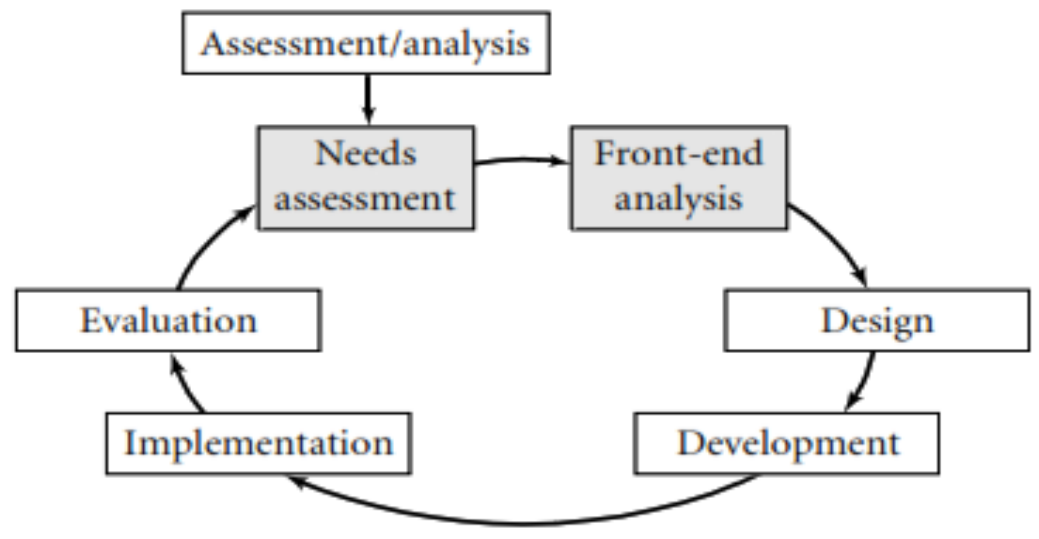

Gambar 1. Model Pengembangan Lee and Owens (Lee O Wens, 2004)

Dalam penelitian ini akan diperoleh dua jenis data, yaitu data kualitatif dan data Kuantitatif. Data kualitatif diperoleh dari data validasi angket berupa kritik, tanggapan dan saran yang diberikan oleh ahli media dan ahli materi serta saran dari guru Matematika dari segi kebahasaan, kelayakan dan kepraktisan dari produk yang telah dikembangkan. Untuk data kuantitatif, diperoleh dari hasil skor yang diberikan oleh uji coba kelompok kecil dan kelompok besar serta skor hasil belajar. Analisis data untuk kevalidan materi dan media menggunakan skala 1 dan 0 . Untuk validasi materi terdiri atas 18 item pernyataan dan ahli media 15 item pernyataan. penilaian guru, uji kelompok kecil dan uji coba kelompok besar menggunakan skala likert 1- 5. Penilaian guru terdiri atas 20 item pertanyaan, ujicoba kelompok kecil dan ujicoba kelompok besar 10 item pertanyaan. Pada ujicoba kelompok kecil terdiri atas 8 siswa yang heterogen sedangkan pada ujicoba kelompok besar 28 siswa. Analisis data dicari dengan menggunakan persamaan

$$
\text { Rentang Nilai }=\frac{\text { Skor maksimal }- \text { skor minimal }}{\text { Kategori kriteria }}
$$

$$
\text { Persentase }=\quad \frac{\text { Jumlah skor yang diperoleh }}{\text { skor maksimal }} \times 100 \%
$$

Tabel 1. Kategori Penilaian Validasi Mobile learning Ahli Media

\begin{tabular}{|c|c|l|}
\hline Skor total & Persentase $\mathbf{( \% )}$ & \multicolumn{1}{|c|}{ Tingkat kategori } \\
\hline $13 \leq \mathrm{x} \leq 15$ & $81-100$ & Sangat valid \\
\hline $10 \leq \mathrm{x} \leq 12$ & $61-80$ & Valid \\
\hline $7 \leq \mathrm{x} \leq 9$ & $41-60$ & Cukup valid \\
\hline $4 \leq \mathrm{x} \leq 6$ & $21-40$ & Kurang valid \\
\hline $0 \leq \mathrm{x} \leq 3$ & $0-20$ & Tidak valid \\
\hline
\end{tabular}

Tabel 2. Kategori Penilaian Validasi Mobile learning Ahli Materi

\begin{tabular}{|c|c|l|}
\hline Skor total & Persentase (\%) & Tingkat kategori \\
\hline $16 \leq_{\mathrm{x}}<20$ & $81-100$ & Sangat valid \\
\hline $12 \leq_{\mathrm{x}}<16$ & $61-80$ & Valid \\
\hline $8 \leq_{\mathrm{x}}<12$ & $41-60$ & Cukup valid \\
\hline
\end{tabular}




\begin{tabular}{|l|c|l|}
\hline $4 \leq \mathrm{x}<8$ & $21-40$ & Kurang valid \\
\hline $0 \leq \mathrm{x}<4$ & $0-20$ & Tidak valid \\
\hline
\end{tabular}

Tabel 3. Kategori Penilaian Respon Guru

\begin{tabular}{|c|c|l|}
\hline Skor total & Persentase (\%) & Tingkat kategori \\
\hline $84 \leq_{\mathrm{x}} \leq 100$ & $84-100$ & Sangat Praktis \\
\hline $68 \leq_{\mathrm{x}}<84$ & $68-83$ & Praktis \\
\hline $52 \leq \mathrm{x}<68$ & $52-67$ & Cukup Praktis \\
\hline $36 \leq \mathrm{x}<52$ & $36-51$ & Kurang Praktis \\
\hline $20 \leq \mathrm{x}<36$ & $20-35$ & Tidak Praktis \\
\hline
\end{tabular}

(Diadopsi dari Jihat dan Haris (2012)

Untuk melihat keefektifan media digunakan uji $\mathrm{N}$-gain untuk melihat hasil belajar sebelum dan sesudah penggunaan media.

Tabel 4. Nilai Skor N-gain dan Kategorinya

\begin{tabular}{|l|l|}
\hline \multicolumn{1}{|c|}{ Skor N-gain } & \multicolumn{1}{c|}{ Kategori } \\
\hline $\mathrm{N}$-gain $\geq 0,70$ & Tinggi \\
\hline $0,30 \leq \mathrm{N}$-gain $<0,70$ & Sedang \\
\hline $\mathrm{N}$-gain $<0,30$ & Rendah \\
\hline
\end{tabular}

(Warda,2018)

\section{HASIL DAN DISKUSI}

Penelitian ini menggunakan model pengembangan Lee \& OWens. Model Pengembangan ini didesain dengan menggunakan lima tahap meliputi tahap analisa (analyze) yang meliputi analisis kebutuhan dan analisis awal akhir, desain (design), pengembangan (develop), implementasi (implementation), dan penilaian (evaluate).

Analyze

Tahap analisis merupakan tahap awal yang dilakukan pada penelitian pengembangan. Tahap analisis dilakukan untuk mengetahui kondisi di lapangan dan mengumpulkan informasi yang berkaitan dengan proses pembelajaran. Tahap analisis pada model Lee\&Owens meliputi tahap analisis kebutuhan dan analisis front-end (awal-akhir). Tahap analisis terdiri atas analisis kebutuhan, wawancara dan menyebarkan angket analisis kebutuhan kepada siswa. Sedangkan analisis front end terdiri atas; analisis siswa, analisis teknologi, analisis tujuan, analisis media serta analisis biaya.

Dari hasil wawancara diperoleh kesimpulan bahwa media yang sering digunakan adalah powerpoint, LKS dan buku cetak serta media yang tersedia di kelas; siswa belum terbiasa dengan soalsoal non rutin; mengingat kondisi yang terjadi saat ini dimana pandemi Covid 19 melanda seluruh dunia tak terkecuali, seluruh kegiatan pembelajaran dialihkan dari offline menjadi online dengan memanfaatkan perangkat informasi dan komunikasi diantaranya handphone maka dibutuhkan alternatif media yang sesuai dengan kondisi saat ini yaitu media mobile learning. Dari hasil observasi diperoleh bahwa madrasah tempat penelitian sudah memiliki fasilitas pendukung yang menunjang proses pembelajaran matematika diantaranya HP baik siswa maupun guru; setiap ruang kelas terdapat aliran 
listrik serta mempunyai infokus yang bisa digunakan saat proses belajar mengajar. Selain itu, telah tersedia perangkat pembelajaran yang dimiliki guru dalam rangka menunjang kegiatan pembelajaran diantaranya buku cetak, Lembar Kerja Siswa (LKS), silabus dan RPP.

Angket analisis kebutuhan diberikan kepada siswa untuk mengetahui apakah media yang akan dikembangkan dibutuhkan oleh siswa dan untuk melihat respon awal siswa sebelum diberikan perlakuan. Berdasarkan hasil angket analisis kebutuhan diperoleh informasi bahwa guru dalam pembelajaran sudah menggunakan media dalam mengajar diantaranya powerpoint dan media yang digunakan belum bervariasi sehingga diperlukan variasi baik dalam penggunaan media atau pendekatan yang digunakan dalam pembelajaran. Dari hasil angket, media yang memanfaatkan teknologi seperti smartphone android belum digunakan dalam pembelajaran sehingga perlu adanya pengembangan media yang memanfaatkan teknologi dan informasi seperti smartphone android, dimana siswa siswa sudah memiliki handphone sehingga bisa mencari informasi di mana saja yang menunjang pembelajaran

\section{Design}

Tahap ini terdiri atas: membuat jadwal dalam pengembangan media; merancang spesifikasi media yang akan dikembangkan; merancang materi yang akan dikembangkan; menyiapkan perangkat yang diperlukan dalam pengembangan media. Jadwal Pengembangan media berlangsung dari bulan Januari - Mei 2021, setelah itu merancang spesifikasi media. Rancangan spesifikasi media terdiri atas:

1. Media ini dibuat dengan menggunakan laptop dengan bantuan aplikasi Smart Apps Creator

2. Video pada media pembelajaran dibuat dengan berbantuan software aplikasi powerpoint dan camtasia.

3. Materi yang akan dirancang pada pengembangan media mobile learning ini adalah turunan fungsi kelas XI MIA di MAN 2 Kota Jambi.

4. Materi yang dibuat disesuaikan dengan KI, KD dan indikator pada silabus serta kurikulum 2013 edisi revisi

5. Produk yang dihasilkan memuat materi, teks, gambar, video dan soal latihan

6. Produk yang dihasilkan terdiri dari Kompetensi Inti, Kompetensi Dasar, tujuan pembelajaran, materi pelajaran, kuis/latihan, video materi pelajaran, profil pengembang dan petunjuk penggunaan.

7. Produk yang dihasilkan dapat diakses melalui smartphone/android

8. Setelah merancang spesifikasi media, selanjutnya membuat storyboard.

\section{Development}

Langkah-langkah yang dilakukan dalam tahap pengembangan ini adalah:

1. Membuat produk media mobile learning dengan pendekatan saintifik berbasis keterampilan berpikir kritis melalui aplikasi smart apps creator 3.

2. Membuat instrument penilaian berupa angket yang terdiri atas angket ahli media, ahli materi, angket uji kelompok kecil dan angket uji kelompok besar serta angket persepsi guru.

3. Produk menjalani tahapan validasi yang dinilai oleh tim ahli yaitu ahli media dan ahli materi. 
4. Melakukan revisi terhadap produk berupa perbaikan produk berdasarkan saran dan masukan dari masing-masing penilaian ahli

Pengembangan media mobile learning terdiri atas beberapa bagian yaitu: desain sampul, identitas pengguna, menu utama yang terdiri atas petunjuk penggunaan, Kompetensi Dasar dan indikator, tujuan pembelajaran, materi pembelajaran, video pembelajaran, LKPD, tes, kesimpulan dan biografi pembuat. Penjelasan singkat mengenai produk ini dijelaskan di bawah ini:

Tabel 7. Tampilan Media Mobile Learning

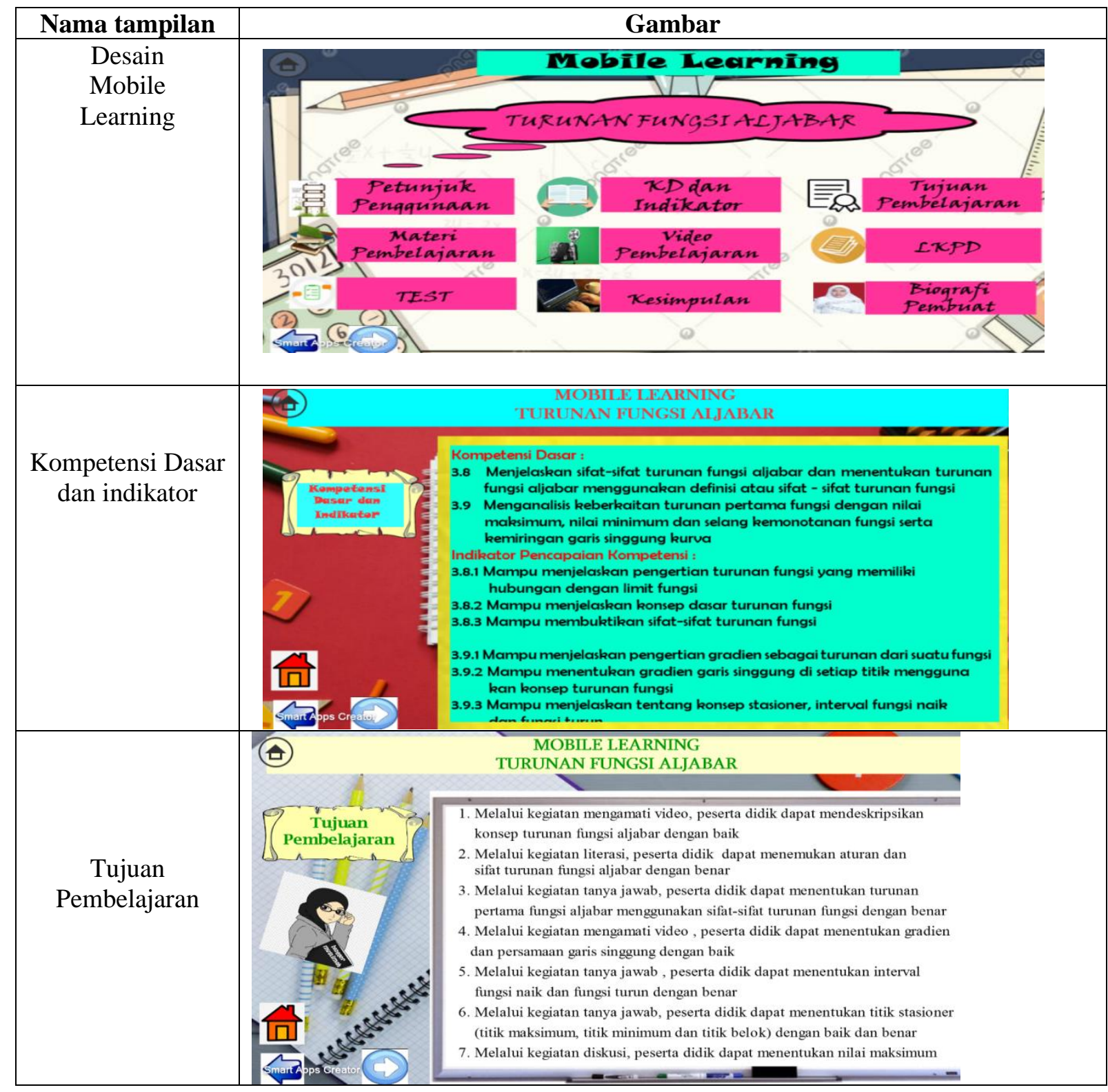


Pengembangan Media Mobile Learning Dengan Pendekatan Saintifik Berbasis Keterampilan Berpikir Kritis Matematis Siswa Kelas XI Madrasah Aliyah, Rini Mariani, Jefri Marzal, Zurweni

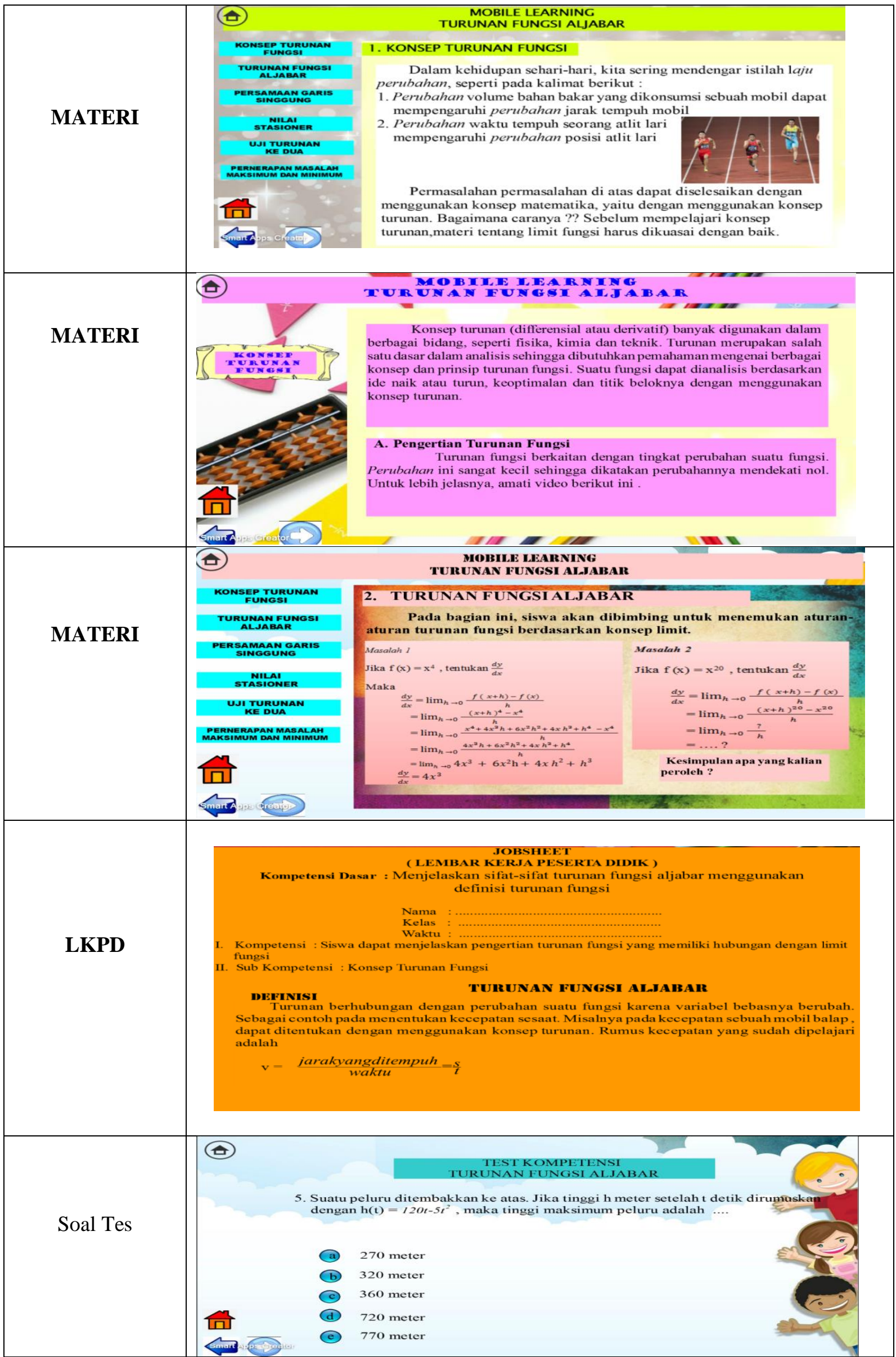


Selanjutnya melakukan validasi kepada dosen Pasca Sarjana Pendidikan Matematika. Validasi ini dilakukan untuk memperoleh produk yang layak dan valid sebelum diujicobakan ke lapangan. Validasi dilakukan dengan memberikan angket yang terdiri atas beberapa pertanyaan dan dilengkapi pula dengan kolom komentar dan saran sebagai bahan masukan dari validator terhadap media yang dikembangkan. Saran - saran dari validator digunakan untuk melakukan revisi produk. Pada validasi materi, validator menyarankan untuk menambahkan indikator berpikir kritis pada media serta tambahkan kesimpulan. Sedangkan pada validasi media, validator menyarankan beberapa hal diantaranya:

1. Warna teks yang terdapat pada media terlalu terang dan melelahkan mata

2. Mengatur tata letak gambar yang sesuai dan proporsional pada halaman yang memuat gambar.

3. Mengatur besar kecilnya tulisan agar dapat dilihat dengan jelas

4. Mengatur kerapian tulisan pada setiap teks dan spasi yang digunakan antara kalimat pada baris pertama dan baris kedua digunakan spasi yang sama dan diatur jarak antara point satu dan point berikutnya

5. Tampilan video diperbesar

Tabel 8. Hasil Revisi Produk

\begin{tabular}{|c|c|c|c|}
\hline Sebelum Revisi & Setelah Revisi \\
\hline 1. Tampilan Warna & \\
Saran : Perbaiki warna pada tulisan & Mobile Learning \\
Saran: Perbaiki warna pada tulisan \\
2. Tulisan pada Kompetensi Dasar dan \\
Indikator terlalu rapat
\end{tabular}


Pengembangan Media Mobile Learning Dengan Pendekatan Saintifik Berbasis Keterampilan Berpikir Kritis Matematis Siswa Kelas XI Madrasah Aliyah, Rini Mariani, Jefri Marzal, Zurweni
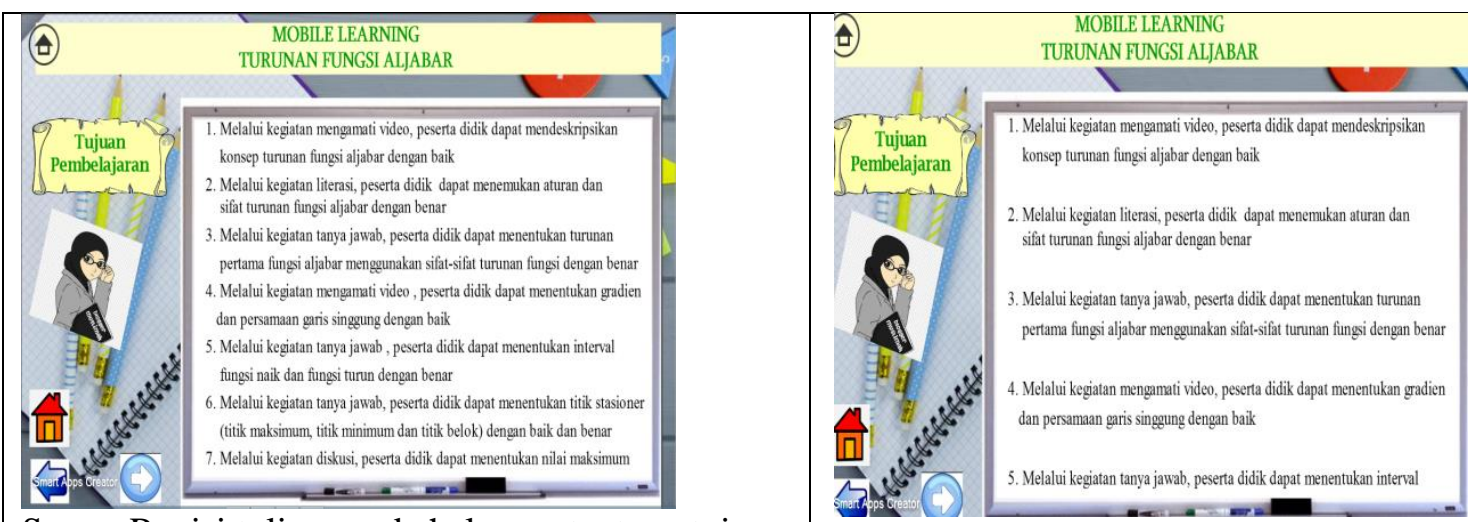

Saran: Revisi tulisan pada halaman tentang tujuan pembelajaran dan jenis huruf

\section{Tampilan Video}

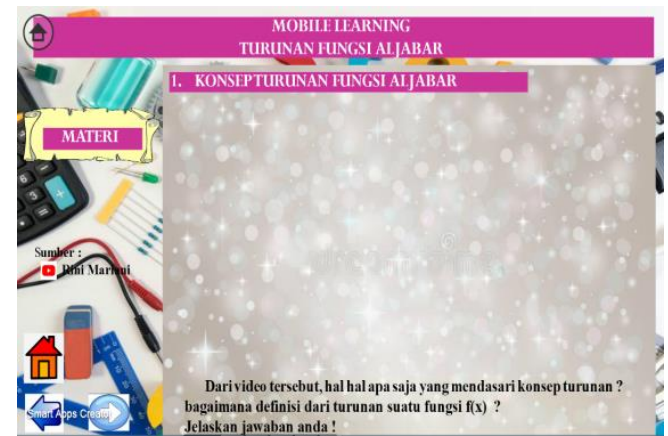

Saran: Tampilan video dibuat lebih lebar

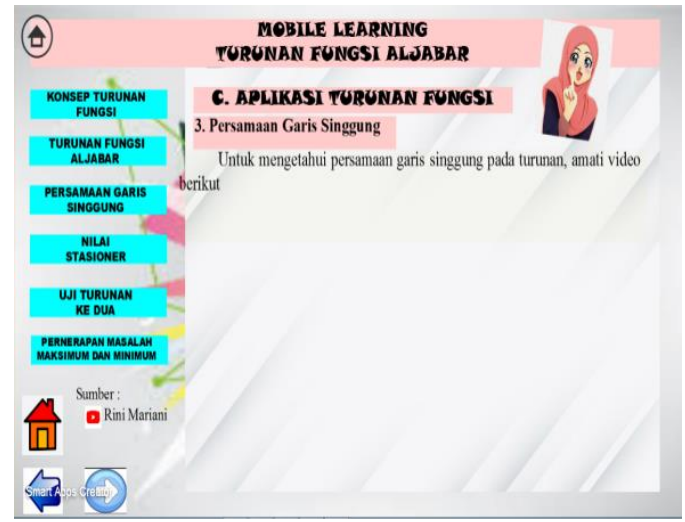

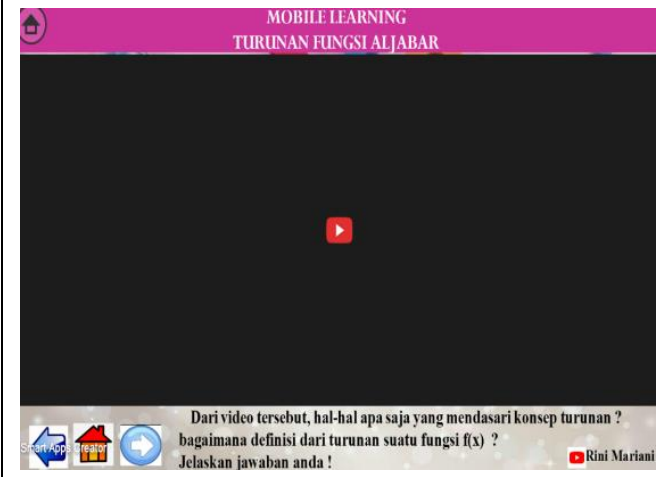

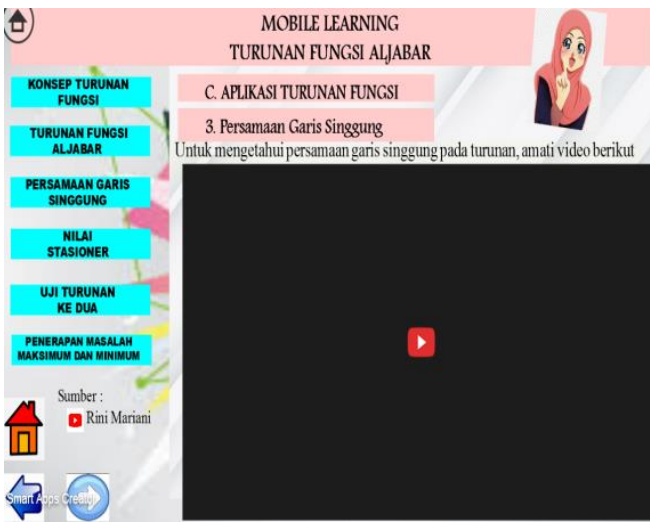

Setelah produk divalidasi dan dinyatakan valid, produk siap diujicobakan pada guru dan siswa. Pada ujicoba perorangan diperoleh kriteria sangat praktis dengan persentase $89 \%$, sedangkan pada ujicoba kelompok kecil diperoleh persentase $86 \%$ dan ujicoba kelompok besar diperoleh persentase $87,5 \%$ dan dalam kategori sangat praktis. Setelah itu, melakukan pembelajaran di kelas dan melakukan pretest dan post test untuk melihat keefektifan media yang dikembangkan. Dari hasil post test dan pretest diperoleh nilai $\mathrm{N}$-gain 0,61 dan dalam kategori sedang. 


\section{Diskusi}

Penelitian yang dilakukan merupakan jenis penelitian pengembangan dengan menggunakan model Lee dan Owens, yang terdiri atas lima tahap. Dimana pada masing masing tahap dilakukan secara berkelanjutan sehingga diperoleh suatu media yang valid, praktis dan efektif. Berdasarkan hasil analisis diperoleh kesimpulan bahwa siswa lebih senang jika digunakan media pada pembelajaran, dan siswa menanggapi secara positif mengenai media untuk pembelajaran matematika yang bisa di akses di mana saja dan kapan saja tanpa terkendala jarak, ruang dan waktu yaitu mobile learning. Hal ini sejalan dengan penelitian (Sastrawati \& Novallyan, 2017; Wulandari et al., 2019) dimana m-learning dapat memudahkan siswa belajar dimana saja dan kapan saja. Media yang dikembangkan berupa apk yang nantinya bisa dibuka di HP android siswa.

Media mobile learning cocok digunakan di sekolah tempat penelitian karena sekolah tempat penelitian sudah tersedia jaringan listrik, siswa mempunyai HP android serta pandemi covid 19 yang melanda yang mengakibatkan perubahan sistem belajar yang biasanya pembelajaran dilakukan secara langsung beralih ke penggunaan teknologi informasi dan komunikasi seperti handphone dan sesuai dengan era industri 4.0. Penggunaan handphone telah beralih dari yang awalnya hanya untuk komunikasi dan telpon sekarang sudah beralih dijadikan sumber untuk mencari informasi. Berdasarkan analisis karakteristik siswa, usia siswa Madrasah Aliyah berkisar 15-18, yang artinya sudah pada tahap operasi formal yang artinya pada tahap ini siswa sudah bisa berpikir logis, bisa menarik kesimpulan, membuat deduktif dan induktif (Supriyanto, 2013). Berdasarkan teori belajar, artinya pada usia 15-18 tahun siswa sudah bisa diajak untuk berpikir kritis. Terutama pelajaran matematika yang menuntut peserta didik agar berpikir kritis dalam memahami persoalan persoalan dan menyelesaikannya. Sebelum memulai penelitian, peneliti menjelaskan terlebih dahulu mengenai pendekatan saintifik dan indikator berpikir kritis yang akan diterapkan.

Pembelajaran dilakukan sebanyak lima kali pertemuan. Diawal awal pertemuan, siswa masih bingung dalam Pada pertemuan pertama siswa masih bingung dalam menjawab pertanyaan yang diberikan guru dan masih bingung dengan pendekatan dan indikator berpikir kritis yang peneliti sampaikan karena siswa belum terbiasa menggunakannya. Disini guru menjelaskan terlebih dahulu langkah-langkah pembelajaran dan menuntun siswa agar mereka bisa memberikan jawaban-jawaban dan berani mengemukakan pendapat mereka. Pada pertemuan pertama, guru masih membimbing siswa dalam memahami indikator berpikir kritis dan pendekatan saintifk. Pada pertemuan pertama, satu dua saja yang sudah berani mengemukakan pendapatnya dan guru tetap memberikan motivasi kepada siswa agar tetap semangat dalam belajar dan berani mengemukakan pendapatnya motivasi kepada siswa agar tetap semangat dalam belajar dan berani mengemukakan pendapatnya. Pada pertemuan kedua, siswa mulai terbiasa menggunakan pendekatan saintifik dan berbicara. Pada pertemuan kedua ini, siswa sudah berani menyampaikan pendapat mereka walaupun apa yang mereka jawab belum tepat dan telah terjadi interaksi antara guru dan siswa, serta siswa dan siswa. Siswa yang lain juga sudah berani menanggapi 
pertanyaan atau jawaban temannya. Satu dua orang siswa sudah bisa menjelaskan kepada rekannya dengan menggunakan bahasa dia sendiri. Di sini, guru juga memberikan penjelasan agar apa yang diterima siswa tidak lari dari konsep yang seharusnya. Pertemuan ketiga dan seterusnya, siswa semakin antusias dan semangat dalam belajar. Hal ini dikarenakan sudah mencoba membaca materi yang ada dirumah karena materi nya bisa mereka baca dimana saja dan tanpa memerlukan kouta untuk membacanya jika mereka sudah mendownload aplikasinya serta pada media sudah dilengkapi dengan materi dan video.

Untuk melihat kelayakan secara praktis dilakukan ujicoba kepada guru dan siswa. Dari hasil ujicoba diperoleh kriteria sangat praktis dikarenakan respon siswa dan guru sangat baik terhadap media tersebut bisa dilihat dari hasil pengisian angket respon siswa dan guru. Selain itu pada media dilengkapi kompetensi dasar, tujuan pembelajaran, petunjuk penggunaan, materi, contoh soal, LKPD, video, serta uji kompetensi. Hal ini sesuai dengan prinsip penggunaan media antara lain: kesesuaian media pembelajaran dengan tujuan pembelajaran, kesesuaian media dengan materi pembelajaran, kesesuaian media dengan kebutuhan dan kondisi siswa serta kesesuaian media dengan kemampuan guru dalam menggunakannya. Selanjutnya untuk penyajian dalam kategori sangat praktis. Hal ini karena pada media sudah diberikan petunjuk penggunaan, sudah diberikan hyperlink sehingga pengguna bisa memilih menu sajian dengan baik serta mudah dalam penggunaannya. Selain itu, pada media menggunakan kalimat yang sederhana dan mudah dipahami oleh siswa.

Berdasarkan hasil ujicoba, siswa berpendapat bahwa penyajian media menarik dan ukuran teks dapat terbaca dengan baik. Untuk aspek materi, materi yang ada pada media disertai gambar dan video agar membantu siswa mudah memahami materi tersebut serta dihubungkan dengan berpikir kritis dan pendekatan saintifik. Hal ini sesuai dengan pendapat Nieven (1999) bahwa media pembelajaran dikatakan praktis jika guru dan siswa mempertimbangkan perangkat pembelajaran mudah digunakan dilapangan dan sesuai dengan rencana perancangan peneliti. Media pembelajaran dikatakan praktis jika para responden (dalam hal ini adalah guru dan siswa) memberikan respon positif dan menyatakan perangkat pembelajaran dapat digunakan dalam pembelajaran, ditunjukkan oleh angket atau kuisioner yang diisi oleh guru dan siswa. Berdasarkan penjelasan diatas dimana guru dan siswa memberikan respon positif dan menyatakan bahwa media mudah digunakan dalam pembelajaran maka media pembelajaran berbasis keterampilan berpikir kritis telah memenuhi semua indikator kepraktisan dan dinyatakan praktis.

Pada materi turunan fungsi aljabar, peneliti sebelumnya melakukan pretest sebelum memulai pembelajaran untuk melihat kemampuan awal siswa, setelah mengoreksi hasil tes peneliti membuat analisis butir soal dari hasil tes. Dari hasil tes awal, siswa belum terbiasa membuat diketahui dan ditanya dari suatu persoalan (indikator memberikan penjelasan sederhana). Pentingnya membuat diketahui dan ditanya dari suatu persoalan agar siswa mengerjakan soal lebih terarah dan sesuai prosedur yang ditetapkan. Berdasarkan hasil post test terdapat peningkatan hasil belajar siswa. Hal ini dikarenakan media sudah dilengkapi dengan gambar, teks, serta video pembelajaran untuk memudahkan siswa dalam 
memahami materi. Pada media juga terdapat indikator berpikir kritis misalnya memberikan penjelasan sederhana, dimana indikatornya adalah merumuskan permasalahan yang ditunjukkan dengan dapat menuliskan yang diketahui dan yang ditanyakan dari soal dengan tepat dan lengkap.

Keefektifan media pembelajaran juga dapat dinilai dari hasil observasi dilapangan ketika menggunakan media mobile learning., diantaranya: (1) Media mobile learning berbasis aplikasi android membantu siswa untuk lebih fokus mengikuti pembelajaran hal ini terlihat dari perhatian siswa saat membaca materi. (2) Media mobile learning berbasis android membantu siswa untuk aktif dalam mengikuti pembelajaran, hal ini terlihat dengan keterlibatan siswa dalam memahami materi pelajaran dan menjawab pertanyaan-pertanyaan yang ditampilkan pada media (3) Media pembelajaran mobile learning dapat membangkitkan motivasi siswa. (4) Media pembelajaran mobile learning membantu siswa untuk berpikir kritis, hal ini terlihat dari komentar maupun tanggapan siswa mengenai materi yang disampaikan. Sejalan dengan penelitian Attewell, dkk (2009) menyatakan bahwa dengan media mobile learning dapat digunakan di masa yang akan datang dan sesuai dengan perkembangan ilmu pengetahuan dan teknologi yang semakin cepat. Selain itu, media mobile learning memiliki dampak yang positif bagi siswa yaitu dapat memotivasi siswa dalam belajar serta menarik siswa dalam memahami materi. Suatu media dikatakan efektif apabila siswa berhasil dalam proses pembelajaran dan terdapat kekonsistensian antara kurikulum, pengalaman belajar siswa dan pencapaian proses pembelajaran yang dilihat dari hasil belajar siswa. Halini sesuai dengan pendapat Nieven (1999) yakni indikator untuk menyatakan suatu pengembangan dalam pembelajaran efektif yakni dilihat dari tes hasil belajar. Dengan demikian, kriteria efektivitas yaitu ketuntasan belajar siswa telah terpenuhi karena pada hasil post test presentase ketuntasan belajar siswa sudah mengalami peningkatan.

\section{KESIMPULAN}

Penelitian ini menggunakan model pengembangan Lee dan Owens, yang terdiri atas analisis, desain, development, implementasi dan evaluasi. Media yang dikembangkan terdapat unsur berpikir kritis. Media yang dikembangkan dikatakan layak jika memenuhi tiga aspek yaitu valid, praktis dan efektif. Berdasarkan validasi dari validator dan saran saran yang diberikan vvalidator menyatakan bahwa media ini sudah valid. Dari ujicoba kepada guru dan siswa diperoleh kriteria sangat praktis. Hal ini karena media ini mudah digunakan dan bisa dipakai dimana saja serta aspek efektif. Media dikatakan efektif apabila terjadi peningkatan hasil belajar siswa sebelum dan sesudah penggunaan media.

\section{UCAPAN TERIMA KASIH}

Penulis mengucapkan puji syukur kepada Allah SWT yang telah memberikan kesehatan dan, kesempatan untuk menyelesaikan tesis ini. Penulis juga mengucapkan terima kasih kepada kedua orangtua, keluarga dan semua saudara yang telah membantu baik secara moril maupun materiil. Terima kasih juga kepada dosen - dosen pasca Sarjana pendidikan matematika yang telah memberikan arahan dan bimbingan selama perkuliahan serta kepada pembimbing yaitu bapak Jefri Marzal dan Ibu zurweni 
yang telah memberikan arahan dan bimbingan dalam penyelesaian tesis ini. Serta seluruh teman teman pasca dan kepala madrasah, guru dan siswa MAN 2 Kota Jambi yang telah membantu dalam penelitian.

\section{REFERENSI}

Apriliyanto, B. (2019). Analisis Kesalahan Siswa dalam Pemecahan Masalah Turunan Fungsi Aljabar. Jurnal Komunikasi Pendidikan, 3(2), 117. https://doi.org/10.32585/jkp.v3i2.300

Ennis, R. H. (2011). The Nature of Critical Thinking: An Outline of Critical Thinking Dispositions and Abilities. Informal Logic, 1-8.

Hosnan. (2014). Pendekatan Saintifik dan Konstektual dalam Pembelajaran Abad 21. Ghalia Indonesia.

Huda, M. M., Susilo, H., \& Sa'dijah, C. (2011). Keterampilan Berpikir Kritis Dalam Penerapan Reciprocal Teaching. Prosiding Seminar Nasional Mahasiswa ..., 1-6. https://core.ac.uk/download/pdf/267023928.pdf

Jihad dan Haris. (2012). Evaluasi Pembelajaran. Multi Pressindo.

Junita, W. (2019). Penggunaan Mobile Learning sebagai Media dalam Pembelajaran. Prosiding Seminar Nasional Teknologi Pendidikan Pascasarjana UNIMED, 602-609. http://digilib.unimed.ac.id/38863/3/ATP 69.pdf

Kabunggul, Y., Pramita, D., Mandailina, V., Abdillah, Mahsup, \& Sirajuddin. (2020). Meningkatkan Motivasi dan Hasil Belajar Siswa Melalui Penerapan Model Pembelajaran Team Game Tournament Berbantuan Media Android. Jurnal Pendidikan Berkarakter, 3(2), 01-04. http://journal.ummat.ac.id/index.php/pendekar/article/view/2804

Kemendikbud. (2014a). Permendikbud Nomor 103 Tahun 2014 tentang Pendekatan Saintifik.

Khaer, A. (2018). Modul Pemanfaatan Aplikasi Smart Apps Creator 3 Dalam Pembuatan Aplikasi Mobile Learning.

Lee, W. W., \& Owen, D. L. (2004). Multimedia Based Instructional Desain Second Edition.

Lestari, A. I., Senjaya, A. J., \& Ismunandar, D. (2019). Pengembangan Media Pembelajaran Berbasis Android Menggunakan Appy Pie Untuk Melatih Pemahaman Konsep Turunan Fungsi Aljabar. Pedagogy: Jurnal Pendidikan Matematika, 4(2), 1-9. https://doi.org/10.30605/pedagogy.v4i2.1437

Nieveen, Akker, J. van, \& Branch, R. M. (1999). Design Approaches and Tools in Education and Training. Kluwer Academic Publisher.

Nugroho, A. A., \& Purwati, H. (2015). Pengembangan Media Pembelajaran Matematika Berbasis Mobile Learning Dengan Pendekatan Scientific. Euclid, 2(1), 174-182. https://doi.org/10.33603/e.v2i1.355

Nurrita, T. (2018). Pengembangan Media Pembelajaran Untuk Meningkatkan Hasil Belajar Siswa. MISYKAT: Jurnal Ilmu-Ilmu Al-Quran, Hadist, Syari'ah Dan Tarbiyah, 3(1), 171. https://doi.org/10.33511/misykat.v3n1.171

Said, K., Kurniawan, A., \& Anton, O. (2018). Development of Media-Based Learning Using Android Mobile Learning. Journal of Theoretical and Applied Information Technology, 96(3). 
Salahuddin, Akos, M., \& Hermawan, A. (2018). Meningkatkan Mutu Pendidikan Melalui Sumber Daya Manusia dan Sarana Prasarana Di MTsN Banjar Selatan 2 Kota Banjarmasin. Jurnal Ilmu Administrasi Dan Manajemen, 2(1), 1-13.

Samsinar, S. (2020). Mobile Learning: Inovasi Pembelajaran di Masa Pandemi COVID-19. Al-Gurfah : Journal of Primary Education, 1(1), 41-57.

Sastrawati, E., \& Novallyan, D. (2017). Pengembangan Media Pembelajaran Interaktif Berbasis Android untuk Pemahaman Konsep Trigonometri. Jurnal IJER, 2(2), 72-76. http://edujurnal.iainjambi.ac.id/index.php/ijer IJER,

Sulistiani, E., \& Masrukan. (2016). Pentingnya Berpikir Kritis dalam Pembelajaran Matematika untuk Menghadapi Tantangan MEA. Seminar Nasional Matematika X Universitas Semarang 2016, 605612 .

Supriyanto, J. (2013). Cooperative Learning Teori dan Aplikasi PAIKEM. Pustaka Pelajar.

Suryani, N., Musahrain, \& Suharno. (2017). Pengaplikasian Mobile Learning Sebagai Media dalam Pembelajaran Prosiding Seminar Pendidikan Nasional. Prosiding Seminar Pendidikan Nasional, $125-131$.

Tang, T., Vezzani, V., \& Eriksson, V. (2020). Developing critical thinking, collective creativity skills and problem solving through playful design jams. Thinking Skills and Creativity, 37(July), 100696. https://doi.org/10.1016/j.tsc.2020.100696

Warda, A. (2018). Keterampilan Berpikir Kritis Siswa dalam Implementasi Model Discovery Learning pada Sub Materi Pemanasan Global. Jurnal Pensa, 6(2), 1689-1699.

Watson, \& Glaser. (2010). Critical Thinking Appraisal Profil Report. Pearson Education Inc.

Wijaya, E. Y., Sudjimat, D. A., Nyoto, A., \& Malang, U. N. (2016). Transformasi Pendidikan Abad 21 sebagai Tuntutan Pengembangan Sumber Daya Manusia di Era Global. 1, 263-278.

Wijayanti, A., Palittin, I. D., \& Bahri, S. (2019). Analisis Kesulitan Siswa Dalam Menyelesaikan Soal Cerita Fisika Siswa Kelas XI IPA SMA Negeri 1 Tanah Miring Merauke. JPFT (Jurnal Pendidikan Fisika Tadulako Online), 7(1), 46-51. https://doi.org/10.22487/j25805924.2019.v7.i1.12327

Wulandari, D. A., Wibawanto, H., Suryanto, A., \& Murnomo, A. (2019). Pengembangan Mobile Learning berbasis Android pada Mata Pelajaran Rekayasa Perangkat Lunak di SMK Sultan Trenggono Kota Semarang. Jurnal Teknologi Informasi Dan Ilmu Komputer, 6(5), 577. https://doi.org/10.25126/jtiik.201965994

Zubaidah, S. (2010). Berpikir Kritis: Kemampuan Berpikir Tingkat Tinggi Yang dapat Dikembangkan Melalui Pembelajaran Sains. Seminar Nasional Sains 2010 Dengan Tema "Optimalisasi Sains Untuk Memberdayakan Manusia," January 2010, 11. 